\title{
Internal Displacement: Relationship of mental health and education of children in Swat, Pakistan
}

\author{
Nasir Ahmad', Sajjad Hussain², Nasir Shaheen ${ }^{3}$
}

\begin{abstract}
Background and Objectives: Internal displacement causes mental health problems and effect education of school going children. This study intended to find the relationship between mental health problems and education of children displaced during violence in Swat Pakistan.

Methods: This is quantitative co-relational study conducted in Swat, Pakistan during October 2017 to June 2018. The population of the study constitutes all the students of 25 high schools destroyed during violence. Child PTSD symptom scale, Siddiqui-Shah Depression Scale and Beck Anxiety Inventory were used to collect data from the sample (712) students.

Results: High level of PTSD, depression and anxiety were found in female students and those who were not attending schools during displacement. PTSD and depression have negatively affected academic achievements of female students and those students who were out of schools irrespective of their gender. Conclusion: The study concludes that internal displacement causes mental health problems in children which can be minimize through education to a great extent.
\end{abstract}

KEYWORDS: Anxiety, Depression, Education, Internal displacement, PTSD.

How to cite this:

doi: https://doi.org/10.12669/pjms.36.5.1847

Ahmad N, Hussain S, Shaheen N. Internal Displacement: Relationship of mental health and education of children in Swat, Pakistan. Pak J Med Sci. 2020;36(5):909-913. doi: https://doi.org/10.12669/pjms.36.5.1847

This is an Open Access article distributed under the terms of the Creative Commons Attribution License (http://creativecommons.org/licenses/by/3.0), which permits unrestricted use, distribution, and reproduction in any medium, provided the original work is properly cited.

\section{INTRODUCTION}

Disasters whether natural or manmade, it force human beings to displace to safer places. The major cause of this internal displacement is conflicts. Dryden-Peterson ${ }^{1}$ found that only

1. Dr. Nasir Ahmad

Centre for Education and Staff Training,

2. Dr. Sajjad Hussain,

Centre for Education and Staff Training,

3. Dr. Nasir Shaheen,

Centre for Commerce and Management Sciences,

1-3: University of Swat,

Swat, Pakistan.

Correspondence:

Dr. Nasir Ahmad,

Centre for Education and Staff Training,

University of Swat,

Swat, Pakistan.

E-mail: nasir_cupid@uswat.edu.pk

* Received for Publication:

October 30, 2019

* Revision Received:

* Second Revision Received:

December 30, 2019

* Final Revision Accepted: in 2008, 26 million people were internally displaced worldwide. Children are the most disadvantageous segment of human population as displacement makes them vulnerable to mental and physical threats. $\mathrm{UNICEF}^{2}$ estimated that about 17 million children were displaced within their own countries. According to Murthy, ${ }^{3}$ in Cambodia, children were more than half of the internally displaced people although they were only $19 \%$ of the total population.

The most commonly reported psychological problems of internally displaced people were post traumatic stress disorder, depression and anxiety. ${ }^{4}$ Such people face problems like displacement trauma, broken social network, food, shelter, health issues and social discrimination. In recent years large number of population has been displaced. This led to increase in research activities related to mental health problems. Mujeeb et al. ${ }^{5}$ conducted study in Jalozai camp in Pakistan, found that internal 
displacement may bring psychological issues for internally displaced people. The study by Shireen et al. ${ }^{6}$ found a strong association between trauma and mental health. A study by Lamkaddem et $\mathrm{al.}^{7}$ found high prevalence of PTSD among Afghan, Iran and Somali refugees. Likewise, a study conducted in Sri Lanka by Husain et al. ${ }^{8}$ found that people who were displaced and resettled during short term displacement had more symptoms of mental disorders than people who had been displaced for longtime. Morina et al. ${ }^{9}$ studied psychiatric disorders in internally displaced persons, found highest prevalence and variation for: post-traumatic stress disorder (3$88 \%)$, depression (5-80\%), and anxiety disorders $(1-81 \%)$. It is concluded that internally displaced people developed high level of mental health problems. Majority of the displaced people comprised of school going children which have an effect on their routine life including education.

Education is the basic right of every child. The schools are nurseries where young minds are nurtured through education. The hindrance in maintaining education in conflict situation is self-evident as displaced children cannot afford to wait for the conflicts to end so as to exercise their right to education. In almost all of the internal displacements that took place during the last 25 years, children were deprived of equal opportunities and access to education. This deprivation of educational opportunities made these children vulnerable to mental health problems. Usually in disasters like wars schools are either destroyed or used for shelter purposes.

For the last few years a large number of people have been internally displaced in North West of Pakistan. International Displacement Monitoring Center ${ }^{10}$ reported that in last few years almost five million people have been internally displaced in the north-west part of Pakistan. This has been reported as the largest internal displacement in the history of Pakistan. A report by elementary and secondary education Khyber Pakhtunkhwa, Government of Pakistan 11 claimed that 175 primary schools were destroyed in Swat Valley. This destruction has made the situation worse for school going children and consequently thousands of children were left deprived of their basic right to education. A study of three districts in Khyber Pakhtunkhwa, Pakistan found evidences that around 600,000 children had missed one or more years of schooling due to conflicts. ${ }^{12}$ Most of the studies around the world and in Pakistan focused on mental health problems, while ignoring the relationship of mental health problems of internally displaced children with their education during displacement. This study was designed to find the relationship of internal displacement of students with mental health problems and education.

\section{METHODS}

The research was quantitative co relational in nature. The study was conducted in the most affected northern area of Pakistan (Swat) by manmade disaster; As a result, students' education in the region was affected. The study was approved by the ethical committee of University of Swat (Letter No. 878/QEC/UOS Dated September $25,2017)$, after which the study was formally initiated. The total duration of this study was nine months started from October 2017 to June 2018.

The population of the study constituted of student studying in 13 boys and 12 girls' high schools which were destroyed during the violence. The sample consists of 712 secondary school students who have been displaced during the violence. These include 469 male and 243 female students. The inclusion criterion for this study was secondary school students whose schools have been destroyed during the conflict. The Urdu version of Child PTSD symptom scale, Siddiqui-Shah Depression Scale and Beck Anxiety Inventory were used to collect data from the sample students. The marks of students were obtained from their respective schools. Pilot testing of the study was carried out to validate the instruments locally. The instruments were administered to 139 students randomly selected from the population of the study. The Cronbach's coefficient $(\alpha)$ for Saddiqui Shah Depression scale was 0.94 , Beck anxiety Inventory was 0.83 and Child PTSD symptom scale was 0.74 . The instruments were administered to the sample of 712 students for data collection during the class hours. The sample children were informed that the data was being collected for research purpose and the researcher will not share their responses to their teachers and parents. Written informed consent was obtained and students were also informed that they can withdraw there written consent any time. 
Internal Displacement: Relationship of mental health \& education of children

Table-I: Number, Percentage and Place of living of children during Displacement.

\begin{tabular}{lccccc}
\hline Variable & No. & Male & Female & In schools & Out of Schools \\
\hline Camp & $89(12.5 \%)$ & $57(12.1 \%)$ & $32(13.2 \%)$ & $2(2.5 \%)$ & $87(13.7 \%)$ \\
Host Family & $74(10.4 \%)$ & $49(10.4 \%)$ & $25(10.2 \%)$ & $5(6.4 \%)$ & $69(10.9 \%)$ \\
Relative & $305(42.8 \%)$ & $204(43.5 \%)$ & $101(41.6 \%)$ & $41(52.6 \%)$ & $264(41.6 \%)$ \\
Rented House & $244(34.3 \%)$ & $159(33.9 \%)$ & $85(35.0 \%)$ & $30(38.5 \%)$ & $214(33.8 \%)$ \\
\hline Total & $712(100 \%)$ & $469(100 \%)$ & $243(100 \%)$ & $78(100 \%)$ & $634(100 \%)$ \\
\hline
\end{tabular}

\section{RESULTS}

The total respondents of this study were 712 . The results (Table-I) show that $42.8 \%$ of the displaced children were living with relatives and $34.3 \%$ in rented houses. It also shows that majority of the respondents (634) were out of schools during this period. This study also found that female students developed high level of PTSD, depression and anxiety as compare to male students. One major finding of the study was that those students who were not attending school, developed high level of: PTSD, depression and anxiety as compare to those who were attending any school during displacement (Table-II). It also shows that PTSD and depression have negatively affected academic achievements of:

i. Female students.

ii. Those who were out of schools irrespective of their gender. Table-III.

\section{DISCUSSION}

This study intended to find out the relationship of internal displacement with mental health and education of students displaced during violence

Table II: PTSD, Depression and Anxiety among internally displaced children.

\begin{tabular}{lcccc}
\hline Variable & $M$ & S.D & $T$ & $P$ \\
\hline PTSD & & & & \\
Male & 37.13 & 11.38 & 9.01 & $0.000^{*}$ \\
Female & 45.56 & 12.00 & & \\
$\quad$ Attending school & 26.87 & 12.86 & 3.07 & $0.002^{*}$ \\
$\quad$ Not Attending & 32.18 & 13.85 & & \\
Depression & & & & \\
$\quad$ Male & 44.10 & 17.02 & 13.24 & $0.000^{*}$ \\
Female & 64.39 & 11.88 & & \\
$\quad$ Attending school & 44.25 & 15.45 & 2.84 & $0.005^{*}$ \\
$\quad$ Not Attending & 51.93 & 21.59 & & \\
Anxiety & & & & \\
$\quad$ Male & 26.51 & 10.60 & 16.00 & $0.000^{*}$ \\
Female & 41.80 & 13.75 & & \\
$\quad$ Attending school & 26.87 & 12.86 & 3.07 & $0.002^{*}$ \\
$\quad$ Not Attending & 32.18 & 13.85 & & \\
\hline
\end{tabular}

in Swat, Pakistan. It was found that most of the displaced children were living with relatives and in rented houses in other parts of the country and most of them were not attending schools during their displacement. Internally displaced families move to such places where they have relatives or friends who can support them in such situations. Secondly they prefer places where they can afford rent of houses. These findings were supported by Ellison ${ }^{13}$ who observed that most of the displaced children about $85 \%$ to $90 \%$, were living with relatives, friends or in rented rooms in Khyber Pakhtunkhwa. The displaced children living with relative or with host families are likely to miss the opportunity of education than those children who were living in camps. These camps were established by government which were provided with some basic facilities and were also open to international humanitarian agencies. The children living in camps were more accessible to education as some educational facilities were provided to them by government and social organizations. The reports of International

Table III: Relationship of PTSD,

Depression and Anxiety with academic achievements of displaced children.

\begin{tabular}{lc}
\hline PTSD & \\
Male & -0.035 \\
Female & $-0.136^{* *}$ \\
Attending school & -0.030 \\
Not Attending & $-0.139^{* *}$ \\
Depression & \\
Male & -0.028 \\
Female & $-0.217^{* *}$ \\
Attending school & 0.158 \\
Not Attending & $-0.187^{* *}$ \\
Anxiety & \\
Male & -0.029 \\
Female & -0.044 \\
Attending school & 0.189 \\
Not Attending & -0.037 \\
\hline$* *$ Correlation is significant at 0.01 level
\end{tabular}

${ }^{* *}$ Correlation is significant at 0.01 level. 
Displacement Monitoring Center ${ }^{14}$ and ICRC $^{15}$ also confirm the finding of the study.

It was found that female children developed high level of PTSD, depression and anxiety as compare to male children. This finding is consistent with previous research findings that female developed more PTSD, ${ }^{16}$ depression $^{17}$ and anxiety $^{18}$ as compare to male children. Female children developed more mental disorders irrespective of the fact that male are more exposed to trauma. On contrary research studies ${ }^{19}$ shows that those who are more exposed to traumatic events have more chances to develop mental disorders.

The study found that those who were not attending school developed high level of PTSD, depression and anxiety as compare to those who were attending school during displacement. Mooney et al. ${ }^{20}$ confirms that in conflict situation the right to education is violated and the standard development of the children is hindered. Education is critically important for displaced children because children feel normal when they go to school daily in routine just like their homes. The result of this study was in conformity with Amone-P'Olak et al., ${ }^{21}$ Catani et al. ${ }^{22}$ and Gibson et al. ${ }^{23}$ who found mental disorders in children who missed school in conflict zones. The provision of education is of critical importance for displaced children. The environment of school provides a sense of normality, a safe space and psychological support. During internal displacement the classroom environment can act as a safe haven in the world for a child whose life has been turned upside down by armed conflict. Fazal et al. ${ }^{24}$ and Imran et al. ${ }^{25}$ concludes that School is the most easily available system of care that can be used as an opportunity to treat mental health problems of children.

\section{CONCLUSION}

Therefore, the study concludes that the internal displacement causes mental health problems in children which can be minimize through education to a great extent.

Limitations of study: Majority of the students living in the valley were internally displaced. This research was limited to a small sample of those students whose schools have been destroyed in the time of the conflict. The use of large sample and cross sectional research design would improve the results of future studies.
Recommendations: It was recommended that continuity of children education may be ensured during displacement and this may be incorporated in the disaster management policy of the state. In order to address mental health problems of internally displaced children, special courses that can be delivered in the form of motivational plays, music and storytelling may be incorporated in the curriculum.

\section{REFERENCES}

1. Dryden-Peterson, S., 2009. Barriers to Accessing Primary Education in Conflict-Affected Fragile States. [online] pp.1-74. Available at: <https://projects.iq.harvard.edu/ files/wcfia/files/2942.pdf > [Accessed 19 December 2019].

2. UNICEF. The State of the World's Children-Special Edition: Celebrating 20 Years on the Convention on the Rights of the Child: Executive Summary. UNICEF; 2009.

3. Murthy RS, Lakshminarayana R. Mental health consequences of war: A brief review of research findings. World Psychiatry. 2006;5(1):25.

4. Ahmad N, Hussain S, Munir N. A tale of internal displacement: Post Traumatic Stress Disorder (PTSD) among school students in Swat, Pakistan. Rawal Med J. 2018;43(3):511-514.

5. Mujeeb A. Mental health of internally displaced persons in Jalozai camp, Pakistan. Int J Soc Psychiatr. 2015;61(7):653659. doi: $10.1177 / 0020764015573083$

6. Shireen F, Janapana H, Rehmatullah S, Temuri H, Azim F. Trauma experience of youngsters and Teens: A key issue in suicidal behavior among victims of bullying. Pakistan journal of medical sciences. 2014 Jan;30(1):206. doi: 10.12669/pjms.301.4072

7. Lamkaddem M, Essink-Bot ML, Deville W, Gerritsen A, Stronks K. Health changes of refugees from Afghanistan, Iran and Somalia: The role of residence status and experienced living difficulties in the resettlement process. 2015;25(6):917-922. doi: 10.1093/eurpub/ckv061

8. Husain F, Anderson M, Cardozo BL, Becknell K, Blanton C, Araki D, et.al. Prevalence of war-related mental health conditions and association with displacement status in postwar Jaffna District, Sri Lanka. JAMA. 2011;306(5):522531. doi: 10.1001/jama.2011.1052

9. Morina N, Wicherts JM, Lobbrecht J, Priebe S. Remission from post-traumatic stress disorder in adults: A systematic review and meta-analysis of long term outcome studies. Clin Psychol Rev. 2014;34(3):249-255. doi: 10.1016/j. cpr.2014.03.002

10. International Displacement Monitoring Center. Global Overview 2014: people internally displaced by conflict and violence. 2014. Retrieved from: http:/ / www.internaldisplacement.org/publications/2014/global-overview2014-people-internally-displaced-by-conflict-and-violence

11. Government of Pakistan. Khyber Pakhtunkhwa Elementary and Secondary Education. Number of institutions damaged due to law and order situation in Malakand Division. 2012. Retrieved from: http://www. kpese.gov.pk/emergencyEdu.html

12. Ferris E, Winthrop R. Education and displacement: Assessing conditions for refugees and internally displaced persons affected by conflict. Background paper for the EFA Global Monitoring Report 2011. The hidden crisis: Armed conflict and education. 2010. 
13. Ellison CS, Smith A, editors. Education and internally displaced persons. A\&C Black; 2012 Dec 20.

14. International Displacement Monitoring Center. Global Overview 2014: People internally displaced by conflict and violence. 2014. Retrieved from: http:/ / www.internaldisplacement.org/publications/2014/global-overview2014-people-internally-displaced-by-conflict-and-violence

15. International Committee of the Red Cross. Internal displacement in armed conflict: facing up to the challenges. 2009. Retrieved from: https://www.icrc.org/eng/ resources/documents/publication/p4014.htm

16. Ahmad N, Hussain S, Munir N. A tale of internal displacement: Post Traumatic Stress Disorder (PTSD) among school students in Swat, Pakistan. Rawal Med J. 2018;43(3):511-514.

17. Ghaedi L, Mohd Kosnin A. Prevalence of depression among undergraduate students: Gender and age differences. Int J Psychol Res. 2014;7(2):38-50.

18. Slone M, Mayer Y. Gender differences in mental health consequences of exposure to political violence among Israeli adolescents. Child Youth Serv Rev. 2015;58:170-178. doi: 10.1007/s11920-016-0684-3

19. Pennington ML, Carpenter TP, Synett SJ, Torres VA, Teague J, Morissette SB, et.al. The influence of exposure to natural disasters on depression and PTSD symptoms among firefighters. Prehosp Disaster Med. 2018;33(1):102108. doi: 10.1017/S1049023X17007026

20. Mooney E. The concept of internal displacement and the case for internally displaced persons as a category of concern. Refug. Surv. Q. 2005;24(3):9-26. doi: 10.1093/ rsq/hdi049

21. Amone-P'Olak K, Ovuga E, Croudace TJ, Jones PB, Abbott R. The influence of different types of war experiences on depression and anxiety in a Ugandan cohort of war-affected youth: the WAYS study. Soc Psych Epid. 2014;49(11):1783-1792. doi: 10.1007/s00127-014-0873-5
22. Catani C, Schauer E, Elbert T, Missmahl I, Bette JP, Neuner F, et al. Child labor, and family violence: Life adversities and PTSD in a sample of school children in Kabul. J Trauma Stress. 2009;22(3):163-171. doi: 10.1002/jts.20415

23. Gibson LE, Anglin DM, Klugman JT, Reeves LE, Fineberg AM, Maxwell SD, et al. Stress sensitivity mediates the relationship between traumatic life events and attenuated positive psychotic symptoms differentially by gender in a college population sample. J Psychiatr Res. 2014;53:111118. doi: 10.1016/j.jpsychires.2014.02.020

24. Fazel M, Patel V, Thomas S, Tol W. Mental health interventions in schools in low-income and middle-income countries. The Lancet Psychiatry. 2014; 1(5):388-398. doi: 10.1016/S2215-0366(14)70357-8

25. Imran N, Rahman A, Chaudhry N, Asif A. World Health Organization "School Mental Health Manual" based training for school teachers in Urban Lahore, Pakistan: Study protocol for a randomized controlled trial. Trials. 2018;19(1):1-8.doi: https://doi. org/10.1186/s13063-018-2679-3

\section{Author's Contribution:}

NA: Conception and design, responsible and accountable for the accuracy and integrity of the study.

NA \& SH: Collection of data.

NS \& NA: Analysis and interpretation of the data and drafting of the article.

NA \& NS: Critical revision of the article.

SH: Statistical analysis. 